\title{
Serum urea and protein concentrations and growth rate of weanling foals
}

\author{
M. T. Saastamoinen \\ Agricultural Research Centre, Equine Research, Ypäjä, Finland
}

\begin{abstract}
Summary
Serum urea level of weanling foals increased slightly with age, but the level of serum protein remained rather constant. The increment of serum urea values with age was largest in foals fed the poorest protein quality. Correspondingly, serum protein concentrations were higher in foals fed diets not optimized for the amino acid intake, compared to the average protein serum levels. There was a negative regression between average daily gain (ADG) and serum urea concentration, i.e. serum urea increased when ADG decreased. ADG between 10 to 12 months was $15 \%$ slower on average than between 7 to 10 months.
\end{abstract}

keywords: foal, growth, horse, nutrition, protein

\begin{abstract}
Serum Harnstoff- und Eiweißkonzentration sowie Wachstumsraten bei Absetzfohlen
Bei 105 abgesetzten Fohlen wurden vom 7. bis zum 12. Lebensmonat die Konzentrationen von Harnstoff und Gesamteiweiß im Serum untersucht. Die täglichen Zunahmen der Fohlen differierten altersbedingt: zwischen dem 10. und 12. Lebensmonat wurden um 15\% geringere Zunahmen beobachtet als zuvor zwischen dem 7. und 10. Monat. Die Serumharnstoffkonzentrationen stiegen bei Fohlen nach dem Absetzen mit zunehmendem Alter leicht an, während die Gesamteiweißgehalte weitgehend konstant blieben. Der Anstieg der Harnstoffwerte war am größten bei Tieren mit der qualitativ ungünstigsten Eiweißversorgung. Die Serumeiweißkonzentration waren bei Fohlen mit nicht optimal balancierter und forcierter Rohprotein- und Aminosäurenaufnahme erhöht. Es bestand eine signifikante negative Regression zwischen den Harnstoffkonzentrationen im Blutserum und täglichen Zunahme an Körpermasse.
\end{abstract}

Schlüsselwörter: Eiweiß, Ernährung, Fohlen, Pferd, Wachstum

\section{Introduction}

The concentration of urea in the blood can be used as an indicator of protein content and protein quality of feed (Eggum 1970). It has also been suggested that blood urea concentration is a useful tool in determining protein and lysine requirements in pigs (e.g. Coma et al. 1995; Chen et al. 1995). This is based on the fact that nitrogen metabolism responds rapidly to changes in the dietary concentration of amino acids. Blood serum protein levels, in turn, have been measured in several studies to demonstrate the ability of dietary proteins to maintain body protein reserves. However, if these blood metabolites are to be used in growing animals, it is important to know the factors which influence them as well as their relationship to the growth rate and age of the animal.

The aim of this study was to investigate the fluctuation of serum urea and protein levels with age, and to determine the relationship between blood metabolites and the age and growth rate of the foal. The validity of using serum total protein and urea concentrations as possible indicators of protein utilization and requirements is also discussed below.

\section{Material and methods}

Data were pooled on the total protein and urea concentrations in the blood serum of 105 healthy weanling foals (73 Finnhorses, 19 Standardbreds, 13 Warmblooded riding horses). Blood samples were taken at ages of 7, 8, 9, 10 , 11 and 12 months from the jugular vein into evacuated blood collection tubes approximately $2 \frac{1}{2}$ hours after feed ingestion had started. Serum protein levels $(\mathrm{g} / \mathrm{l})$ were measured colorimetrically using the biuret method (Weichselbaum 1946) and serum urea levels were determined (mmol/l) enzymatically (Hallet and Cook 1971).

The average daily weight gain (ADG) between 7 and 10, 10 and 12 , and 7 and 12 months of age was calculated based on the weights recorded at those ages.

For statistical analysis, the foals were allotted to eight dietmanagement classes (Tab.1). The average amino acid and digestible crude protein intakes were then calculated for each class. The serum protein and urea concentrations were adjusted for sex, breed and diet-management effects. The accurate age of the foal was included in the statistical model as a covariate. The data were subjected to a regression analysis and an analysis of variance. The statistical significance of the effects of sex, breed and diet-management class was tested by the F-test.

\section{Results and discussion}

Figure 1 illustrates changes of serum urea levels in weanling foals. Serum urea level was found to increase slightly with age (,Mean“ in Fig.1). The increment of serum urea 
$\mathrm{mmol} / \mathrm{l}$

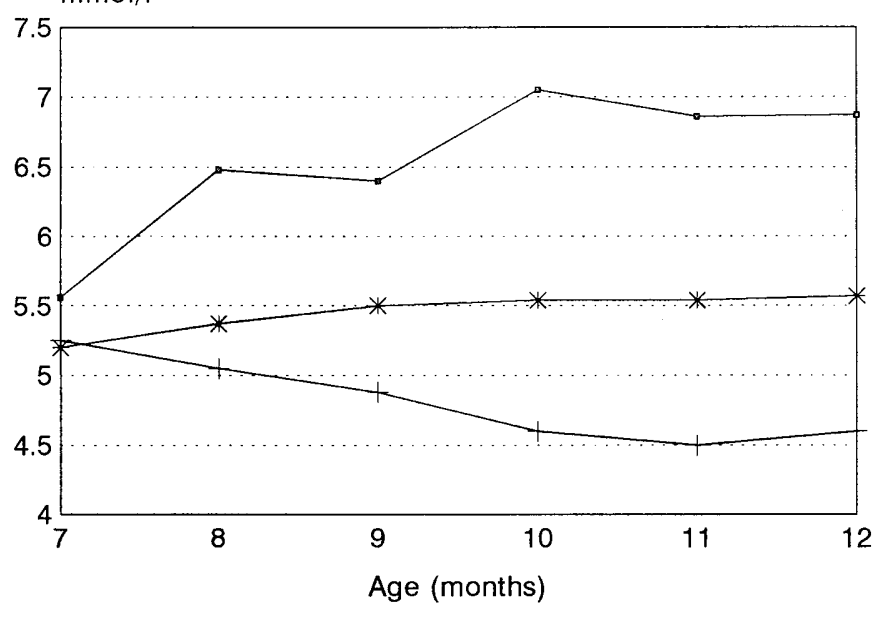

Fig.1: Changes of serum urea levels in weanling foals on an average and fed with poor or high quality protein (Data from the 105 foals in the 8 diet-management classes).

Veränderungen der Serum-Harnstoffpegel, Durchschnittswerte sowie Gruppen mit der geringsten und höchsten Proteinqualität (105 Fohlen von 8 verschiedenen Fütterungsbzw. Haltungsgruppen)

values with age was largest (24\% from 7 to 12 months of age) in foals fed the poorest protein quality, i.e. diets not designed to meet the amino acid needs of the foal. On the other hand, there were only minor changes, or the concentration even tended to decrease, when the diets were balanced for the assumed requirement for certain essential amino acids, i.e. when dietary protein quality improved. Furthermore, the increment was largest in Finnhorses; the concentration increased $15 \%$ (from 4.92 to $5.61 \mathrm{mmol} / \mathrm{l})$ between 7 and 12 months of age, perhaps indicating differences in protein utilization and requirement between the breeds. For 7 - and 8-month-old Finnhorses, serum urea levels were lower than those observed for Standardbred and Warmblooded horses of the same age $(p<0.05)$. The sex of the foal did not affect the serum urea levels.

Tab. 1: CP, DCP and DE intakes in different dietmanagement classes.

Aufnahme von Rohprotein (CP), verd. Rohprotein (DCP) und verd. Energie (DE) in den verschiedenen Fütterungsgruppen

\begin{tabular}{|l|c|c|c|c|}
\hline Class & $\mathrm{n}$ & CP g & DCP g & DE MJ \\
\hline 1 & 12 & 779 & 584 & 75 \\
2 & 11 & 781 & 605 & 75 \\
3 & 10 & 703 & 503 & 75 \\
4 & 10 & 790 & 482 & 75 \\
5 & 10 & 788 & 477 & 79 \\
6 & 11 & 844 & 477 & 79 \\
7 & 14 & 820 & 540 & 77 \\
8 & 27 & 820 & 540 & 77 \\
\end{tabular}

Blood urea content has been reported to increase with the protein content of the diet (Eggum 1970; Fonnesbeck and Symons 1969; Yoakam et al. 1978). A nearly linear relationship between protein intake and blood urea level has been observed (Meyer 1983).

Among the major causes of high blood urea concentrations are an intake of protein in excess of the body's requirements, and a low dietary protein quality resulting from the deamination of excess amino acids (Fonnesbeck and Symons 1969). Decreased serum urea levels have been reported in foals (e.g. Graham et al. 1994; Saastamoinen and Koskinen 1993) and in pigs (Coma et al. 1995) after supplementation with lysine and/or threonine and improvement of dietary protein quality. On the other hand, blood urea has shown an increasing trend when concentrations greater than the requirement were fed (Coma et al. 1995). Thus, declined serum urea concentrations may be an indication of improved amino acid balance and decreased deamination of amino acids, i.e. a lower degree of wastage of amino acids by the body. Serum urea concentration also decreases with age, possibly indicating a declined protein requirement (Saastamoinen and Koskinen 1993).

Serum total protein levels remain rather constant from 7 to 12 months of age. The lowest serum protein concentrations (57.4-60.0 g/l) were observed for Standardbred trotter foals, and the highest for Warmblooded foals (60.0-62.3 $\mathrm{g} / \mathrm{l})$. The smallest variation in protein values was observed for Finnhorse foals $(60.0-71.7 \mathrm{~g} / \mathrm{l})$.

The diet-management effect on serum protein levels was statistically significant after the age of 9 months $(p<0.05$ to $p<0.001$ ). Serum concentrations were 8 to $10 \%$ higher in foals fed diets not optimized for amino acid intake compared to the average protein serum levels. These diets had generally higher protein contents, and foals thus responded to the diets with increased serum protein levels. Furthermore, these diets also increased the serum urea levels, obviously due to the catabolism of excess protein. This is also illustrated by the positive correlation $(r=0.35, p<0.01)$ observed between serum protein and urea levels from 10 months of age onwards, simultaneously with a decreased growth rate.

Blood protein levels have been used to monitor the ability of dietary proteins to maintain the body protein reserves. However, many authors have reported that the dietary protein content and quality have affected the blood protein content only slightly or not at all (Reitnour and Salsbury 1976; Goodbee and Slade 1981; Cumbaluk 1990; Saastamoinen and Koskinen 1993; Saastamoinen et al. 1994). Elevated serum protein contents have been reported after moving the foals to pasture feeding (Menp et al. 1988 and 1994), indicating that blood protein content may respond to more considerable differences in the dietary protein content. Cymbaluk (1990) found that the protein content in serum declined with age in horses fed without protein supplementation.

There was a negative regression between average daily weight gain (ADG) and serum urea concentration, i.e. se- 
rum urea increased when weight gain decreased. The regression was statistically significant $(p<0.001)$ between serum urea level at 10 months of age and ADG measured from 7 to 10 months of age. These results suggest a reduced protein requirement and increased catabolism as the growth rate slackens.

The ADG between 10 to 12 months was $15 \%$ slower on average than between 7 to 10 months (Tab. 2). The growth

Tab. 2: Growth rate of weanling foals between different age intervals.

Wachstumsraten der Absatzfohlen in den verschiedenen Altersgruppen

\begin{tabular}{|l|l|c|c|}
\hline \multirow{2}{*}{$\begin{array}{l}\text { Age } \\
\text { (months) }\end{array}$} & Finnhorse & Growth rate $(\mathrm{g} / \mathrm{d}$ ) \\
\hline $7-10$ & $615 \pm 15.8$ & $512 \pm 31.6$ & $694 \pm 29.1$ \\
\hline $10-12$ & $517 \pm 17.2$ & $470 \pm 34.3$ & $560 \pm 31.6$ \\
\hline $7-12$ & $577 \pm 13.3$ & $496 \pm 26.7$ & $643 \pm 24.5$ \\
\hline
\end{tabular}

rate retarded only $8 \%$ in Standardbreds, but in halfbred foals about 18\%. Finnhorses, Standardbreds and Warmblooded achieved 64,62 and $65 \%$ of their total weight gain between 7 to 10 months of age, respectively. Colts gained somewhat $(7 \%)$ faster $(p<0.05)$ than fillies.

It may be suggested that factors confounded with growth rate and growth rhythm should be taken into account when using serum total protein and urea concentrations as possible indicators of protein utilization and requirement. Such factors include sex and breed of the foal as well as individual differences. Furthermore, when blood urea content is used to assess dietary protein quality, it is important to take into account the dietary protein content and time after feeding (Eggum 1970). Energy intake must also be considered (Yongjiu et al. 1995).

\section{Conclusions}

The results indicate that the protein requirement of weanling foals decreases with age, due to a slower growth rate after 9 to 10 months of age. Serum protein and urea concentrations respond to the diet and can be used as indicators of protein utilization and requirement in foals, but it is also necessary to consider breed, sex and individual differences and other factors affecting growth rate in this context.

\section{References}

Chen, H. Y., Miller, P. S., Lewis, A. J., Wolverton, C. K. and Stroup, W. W. (1995): Changes in plasma urea concentration can be used to determine protein requirements of two populations of pigs with different protein accretion rates. J. Anim. Sci. 73: 2631-2639.
Coma, J., Carrion, D. and Zimmerman, D. R. (1995): Use of plasma urea nitrigen as a rapid response criterion to determine the lysine requirement of pigs. J. Anim. Sci. 73: 472-481.

Cymbaluk, N. F. (1990): Using canola meal in growing draft horse diets. Equine Pract. 12:13-19.

Eggum, B. O. (1970): Blood urea measurement as a technique for assessing protein quality. Br. J. Nutr. 24: 983-988.

Fonnesbeck, P. V. and Symons, L. D. (1969): Effect of diet on concentration of protein, urea nitrogen, sugar and cholesterol of blood plasma of horses. J. Anim. Sci. 28: 216-219.

Goodbee, R. G. and Slade, L. M. (1981): The effect of urea or soybean meal on the growth and protein status of young horses. J. Anim. Sci. 53: 670-676.

Graham, P. M., Ott, E. A., Brendermuhl, J. H. and Tenbroeck, S. H. (1994): The effect of supplemental lysine and threonine on growth and development of yearling horses. J. Anim. Sci. 72: 380-386.

Hallett, C. J. and Cook, J. G. H. (1971): Reduced nicotinamide adenine dinucleotide-coupled reaction for emrgency blood urea estimation. Clin. Chim. Acta 35: 33-37.

Meyer, H. (1983): Protein metabolism and protein requirement in horses. Comp.IVth Int. Symp. Protein metabolism and nutrition, pp. 343-364.

Menp, P. H., Pirskanen, A. and Koskinen, E. (1988): Biochemical indicators of bone formation in foals after tranfer from pasture to stables for the winter months. Am. J. Vet. Res. 49: 1990-1992.

Menp, P. H., Alakuijala, L. and Koskinen, E. (1994): Biochemical indicators of suboptimal protein nutrition in growing horses during the first indoor season. Acta Agric. Scand., Sect. A, Anim. Sci., 44: 61-64.

Reitnour, C. M. and Salsbury, R. L. (1976): Utilization of proteins by the equine species. Am. J. Vet. Res. 37: 1065-1067.

Saastamoinen, M. T. and Koskinen, E. (1993): Influence of quality of dietary protein supplement and anabolic steroids on muscular and skeletal growth of foals. Anim. Prod. 56: 135-144.

Saastamoinen, M. T., Hyypp, S. and Huovinen, K. (1994): Effect of dietary fat supplementation and energy-to-protein ratio on growth and blood metabolites of weanling foals. J. Anim. Physiol. a. Anim. Nutr. 71: 179-188.

Saastamoinen, M. T., Hyypp, S. and Nousiainen, J. (1995): Growth and serum amino acids and blood metabolites in weanling foals. Paper. 46th Ann. Meet. of EAAP.

Weichselbaum, T. E. (1946): An accurate and rapid method for the determination of proteins in small amounts of blood serum plasma. Am. J. Clin. Pathol. 16: 40-49.

Yoakam, S. C., Kirkham, W. W. and Beeson, W. M. (1978): Effect of protein level on growth in young ponies. J. Anim. Sci. 46: 983-991.

Yongjiu, C., Zimmerman, D. R. and Ewan, R.C. (1995): Blood urea and amino acid concentrations in pigs of two breed combinations as affected by energy intakes. J. Anim. Sci. 73: 145-150.

Markku T. Saastamoinen

Agricultural Research Centre

Equine Research

FIN-32100 Ypäjä

Finland 